\title{
ANALISIS FAKTOR RISIKO ANGKA KEMATIAN IBU DENGAN PENDEKATAN REGRESI POISSON
}

\author{
PUTRI RIZA CHANIAGO, DODI DEVIANTO, IZZATI RAHMI HG \\ Jurusan Matematika, \\ Fakultas Matematika dan Ilmu Pengetahuan Alam, Universitas Andalas, \\ Kampus Unand Limau Manis, Padang, Indonesia \\ email : Putrichaniago130596@gmail.com
}

\begin{abstract}
Abstrak. Kasus kematian ibu adalah kasus kematian perempuan pada saat hamil atau kematian perempuan dalam kurun waktu 42 hari sejak terminasi kehamilan. Pada tahun 2014 Indonesia belum mampu mencapai target MDGs yaitu penurunan kematian ibu. Kasus jumlah kematian ibu termasuk peristiwa yang dikategorikan kedalam variabel diskrit dan berdistribusi poisson oleh karena itu penelitian tentang jumlah kematian ibu dapat dilakukan dengan pendekatan regenerasi Poisson. Pada penelitian ini variabel prediktor yang signifikan pada model regresi poisson untuk variabel respon angka kematian ibu adalah rasio jumlah puskesmas.
\end{abstract}

Kata Kunci: Angka Kematian Ibu, MGDs, Poisson, Regresi Poisson

\section{Pendahuluan}

Derajat kesehatan merupakan gambaran profil kesehatan individu atau kelompok individu (masyarakat) di suatu daerah. Derajat kesehatan merupakan salah satu indikator keberhasilan pembangunan dan menjadi sasaran Tujuan Pembangunan Berkelanjutan (Sustainable Development Goals / SDGs) yang merupakan tujuan poin ke-3 yaitu Sehat dan Sejahtera. Derajat kesehatan masyarakat dipengaruhi oleh banyak faktor. Faktor- faktor tersebut tidak hanya berasal dari faktor kesehatan seperti pelayanan kesehatan dan ketersediaan sarana dan prasarana, melainkan juga dipengaruhi oleh faktor ekonomi, pendidikan, lingkungan sosial, keturunan, dan faktor lainnya. Situasi derajat kesehatan masyarakat dapat tercermin melalui angka morbiditas, mortalitas, dan status gizi. Angka Kematian Ibu (AKI) termasuk kedalam mortalitas yang dapat menggambarkan situasi derajat kesehatan suatu negara.

Angka Kematian Ibu (AKI) adalah jumlah kematian ibu pada tahun tertentu dan daerah tertentu per 100.000 kelahiran hidup. Dalam menghitung jumlah kasus AKI dibutuhkan jumlah kematian ibu dimana jumlah kematian ibu adalah jumlah kematian perempuan pada saat hamil atau kematian perempuan dalam kurun waktu 42 hari sejak terminasi kehamilan tanpa memandang lamanya kehamilan atau tempat persalinan dan disebabkan oleh kehamilannya atau pengelolaannya [3]. Pada periode $M D G s$, AKI di Indonesia mencapai 305 per 100.000 kelahiran dan merupakan kasus yang cukup tinggi jika di bandingkan dengan kawasan ASEAN karena berada jauh diatas rata-rata yang ditetapkan MDGs yaitu 102 per 100.000 
kelahiran [2], sehingga diperlukan suatu perhitungan yang tepat untuk mengatasi persoalan mengenai kasus AKI di Indonesia.

Poisson merupakan suatu distribusi yang tepat digunakan dalam perhitungan AKI karena kasus kematian ibu memenuhi karakteristik distribusi Poisson yaitu banyaknya hasil percobaan yang terjadi dalam suatu selang waktu atau suatu daerah tertentu, tidak tergantung pada banyaknya hasil percobaan yang terjadi pada selang waktu atau daerah lain yang terpisah dan juga peluang terjadinya suatu hasil percobaan selama suatu selang waktu yang singkat sekali atau dalam suatu daerah yang kecil, sebanding dengan panjang selang waktu tersebut atau besarnya daerah tersebut, dan tidak bergantung pada banyaknya hasil percobaan yang terjadi diluar selang waktu atau daerah tersebut [4]. Asumsi pada penelitian ini adalah peristiwa kematian ibu pada suatu interval waktu yaitu dalam 12 bulan atau satu tahun pada setiap provinsi di Indonesia, sehingga pada penelitian ini akan ditentukan faktor-faktor yang perpengaruh signifikan terhadap AKI dengan menggunakan Regresi Poisson.

\section{Distribusi dan Regresi Poisson}

Kejadian dapat dikatakan berdistribusi Poisson apabila kejadian tersebut terjadi pada selang waktu tertentu atau daerah tertentu. Proses Poisson berhubungan dengan menghitung jumlah suatu kejadian diskrit pada selang waktu kontinu. Distribusi Poisson digunakan untuk kejadian yang acak. Oleh karena itu bentuk Poisson ini cocok untuk memodelkan kasus AKI karena AKI merupakan kasus kejadian acak yang terjadi pada selang waktu atau daerah tertentu . Banyaknya kejadian kecelakaan dalam jangka waktu tertentu di suatu tempat ataupun banyaknya kematian dalam daerah tertentu akibat wabah penyakit merupakan contoh kejadian Poisson.

Variabel random diskrit Y dikatakan berdistribusi Poisson dengan parameter $\lambda$ jika dan hanya jika fungsi probabilitasnya berbentuk seperti pada Persamaan (2.1) berikut, dimana $\lambda$ adalah rata-rata suatu kejadian (y) yang bernilai lebih besar dari nol [4].

$$
f(y ; \lambda)= \begin{cases}\frac{e^{-} \lambda \lambda^{y}}{y !} & ; y=1,2,3, \cdots \\ 0 & ; y \text { lainnya }\end{cases}
$$

dalam hal ini $\lambda$ adalah rata-rata banyaknya hasil percobaan yang terjadi selama selang waktu atau dalam daerah tertentu dan $e=2.71828$.

Regresi Poisson merupakan regresi yang mengacu pada penggunaan data count berdistribusi Poisson. Regresi poisson menggambarkan adanya hubungan antara variabel respon $(\mathrm{Y})$ yang berdistribusi Poisson dengan satu atau lebih variabel prediktor (X). Model Regresi Poisson merupakan model standar data diskrit dan termasuk dalam regresi nonlinier. Model Regresi Poisson ditulis seperti pada Persamaan (2.2) berikut.

$$
X_{i} \sim \operatorname{Poisson}\left(\lambda_{i}\right)
$$

dengan

$$
\lambda_{i}=e^{x_{i}^{T} \beta},
$$


dimana $x_{i}$ adalah variabel prediktor yang dinotasikan sebagai berikut

$$
x_{i}^{T}=\left[\begin{array}{lll}
1 & x_{1 i} x_{2 i} \cdots x_{k i}
\end{array}\right],
$$

$\beta$ adalah parameter regresi poisson yang dinotasikan sebagai berikut

$$
\beta=\left[\beta_{0} \beta_{1} \beta_{2} \cdots \beta_{k}\right]^{T} .
$$

Penaksiran parameter model regresi Poisson menggunakan metode Maximum Likelihood Estimation (MLE), yaitu dengan memaksimumkan nilai fungsi likelihood. Taksiran parameter regresi Poisson dengan metode MLE dilambangkan dengan $\widehat{\beta}$ yang didapatkan dari turunan pertama fungsi log-likelihood terhadap $\beta^{T}$ yang disamadengankan nol. Metode Maximum Likelihood Estimator (MLE) adalah salah satu metode penaksiran parameter yang dapat digunakan untuk menaksir parameter suatu model yang diketahui distribusinya. Sebagaimana diketahui bahwa taksiran parameter menggunakan metode MLE ini adalah melakukan turunan parsial fungsi likelihood terhadap parameter yang akan ditaksir, fungsi kemungkinannya adalah [1]:

$$
\begin{aligned}
L(\beta) & =\Pi_{i=1}^{n} f\left(y_{i} ; \beta\right), \\
& =\Pi_{i=1}^{n} \frac{\left[\exp \left(-x_{i}^{T} \beta\right)\right]_{i}^{y} \exp \left[-\exp \left(x_{i}^{T} \beta\right)\right]}{y_{i} !} .
\end{aligned}
$$

Untuk mempermudah perhitungan mendapatkan taksiran maksimum likelihood dari parameter digunakan fungsi log-likelihood sebagai berikut:

$$
\begin{aligned}
\ln L(\beta) & =\ln \left\{\Pi_{i=1}^{n} \frac{\left[\exp \left(-x_{i}^{T} \beta\right)\right]_{i}^{y} \exp \left[-\exp \left(x_{i}^{T} \beta\right)\right]}{y_{i} !}\right\}, \\
& =\Sigma_{i=1}^{n} \ln \left\{\frac{\left[\exp \left(-x_{i}^{T} \beta\right)\right]_{i}^{y} \exp \left[-\exp \left(x_{i}^{T} \beta\right)\right]}{y_{i} !}\right\}, \\
& =\Sigma_{i}^{n} y_{i}\left(x_{i}^{T} \beta\right)-\exp \left(x_{i}^{T} \beta\right)-\ln \left(y_{i} !\right) .
\end{aligned}
$$

Parameter hasil yang didapatkan adalah parameter hasil eksplisit maka digunakan metode iterasi numerik yaitu Newton Raphson untuk mendapatkan taksiran parameter. Pada metode Newton Raphson diperlukan turunan kedua dari fungsi loglikelihood.

$$
\ln L(\beta)=-\Sigma_{i=1}^{n} e^{x_{i}^{T} \beta}+\sum_{i=1}^{n} y_{i} x_{i}^{T} \beta-\sum_{i=n}^{n} \ln \left(y_{i} !\right) .
$$

Turunan pertama fungsi logaritma likelihood terhadap $\beta^{T}$ adalah

$$
\frac{\partial \ln L(\beta)}{\partial \beta^{T}}=-\sum_{i=1}^{n} x_{i} e^{x_{i}^{T} \beta}+\sum_{i=1}^{n} x_{i} y_{i} .
$$

Turunan kedua fungsi logaritma likelihood terhadap $\beta$ adalah

$$
\frac{\partial^{2} \ln L(\beta)}{\partial \beta^{T} \partial \beta}=-\Sigma_{i=1}^{n} x_{i} x_{i}^{T} e^{x_{i}^{T} \beta} .
$$

Pengujian signifikansi parameter dengan uji serentak bertujuan untuk mengetahui parameter mana saja yang memberikan pengaruh signifikan terhadap model . 
Hipotesis uji serentak adalah

$$
\begin{aligned}
H_{0} & : \beta_{1}=\beta_{2}=\cdots=\beta_{k}=0, \\
H_{1} & : \text { paling sedikit terdapat satu } \beta_{j} \neq 0, \text { dengan } j=1,2, \cdots, k . \\
D(\widehat{\beta}) & =2\left(\frac{L(\widehat{\omega})}{L(\widehat{\Omega})}\right)
\end{aligned}
$$

Apabila terjadi tolak $H_{0}$ dalam uji serentak maka dilanjutkan dengan uji parsial. Hipotesis untuk uji parsial adalah

$$
\begin{aligned}
& H_{0}: \beta_{j}=0, \\
& H_{1}: \beta_{j} \neq 0, \text { dengan } j=1,2, \cdots, k .
\end{aligned}
$$

Statistik uji yang digunakan adalah [5]

$$
Z=\frac{\widehat{\beta}_{j}}{S E\left(\widehat{\beta}_{j}\right)} .
$$

\section{Analisis Faktor Resiko AKI}

Variabel yang digunakan dalam penelitian terdiri dari variabel respon yaitu Angka Kematian Ibu (AKI) per 10000 kelahiran (Y) di Indonesia yang telah digenapkan sesuai aturan penggenapan. Sedangkan variabel prediktor (X) sebanyak sembilan variabel adalah sebagai berikut:

1. Persentase kemiskinan pada masing-masing provinsi di Indonesia $\left(X_{1}\right)$

2. Rasio jumlah puskesmas per 30.000 penduduk pada masing-masing provinsi di Indonesia $\left(X_{2}\right)$

3. Rasio Jumlah Tempat Tidur di Rumah Sakit per 1000 penduduk pada masing-masing provinsi di Indonesia $\left(X_{3}\right)$

4. Rasio Tenaga Kerja Kesehatan di Puskesmas pada masing-masing provinsi di Indonesia $\left(X_{4}\right)$

5. Rasio Tenaga Kerja Kesehatan di Rumah Sakit per 100.000 penduduk pada masing-masing provinsi di Indonesia $\left(X_{5}\right)$

6. Persentase kunjungan ibu hamil dengan K1 pada masing-masing provinsi di Indonesia $\left(X_{6}\right)$

7. Persentase ibu hamil mendapat tablet Fe3 pada masing-masing provinsi di Indonesia $\left(X_{7}\right)$

8. Persentase ibu hamil imunisasi $\mathrm{TT}+2$ pada masing-masing provinsi di Indonesia $\left(X_{8}\right)$

9. Persentase komplikasi yang ditangani kebidanan di puskesmas pada masingmasing provinsi di Indonesia $\left(X_{9}\right)$.

Pada pengujian distribusi Poisson menggunakan uji Kolmogrov-Smirnov, berdasarkan hasil perhitungan pada software SPSS untuk Variabel Respon Angka Kematian Ibu (Y) diperoleh nilai dari $D_{\text {hitung }(y 1)}=0.268$ dan nilai $p-$ value $_{(y)}=$ 0.020 sementara nilai $D_{\text {tabel }}$ untuk uji Kolmogrov-Smirnov adalah 0.288 dengan taraf uji $\alpha=0.01$ dan $N=32$, karena nilai $D_{\text {hitung }(y)}<D_{\text {tabel }}(0.268<0.288)$ 
dan $p-\operatorname{value}_{(y)}>\alpha(0.020>0.01)$ maka variabel respon Angka Kematian Ibu (Y) dapat dikatakan menyebar Poisson. Berdasarkan nilai harapan dan varian dari AKI yaitu 81.16 dan 16.06 maka diperoleh rasio varian terhadap nilai harapan sebesar 5.05 yang lebih besar dari 2.5 sehingga data mengalami overdisversi. Setelah dilakukan perhitungan maka hasil estimasi parameter yang diperoleh adalah sebagai berikut:

Tabel 1. Estimasi parameter Model Regresi Poisson AKI

\begin{tabular}{|c|c|c|c|}
\hline Parameter & Estimasi & $\mathrm{SE}$ & P-Value \\
\hline$\beta_{0}$ & 2.557 & 0.719 & 0.00 \\
$\beta_{1}$ & 0.016 & 0.011 & 0.137 \\
$\beta_{2}$ & 0.137 & 0.075 & 0.068 \\
$\beta_{3}$ & 0.016 & 0.119 & 0.893 \\
$\beta_{4}$ & 0.005 & 0.004 & 0.192 \\
$\beta_{5}$ & -0.003 & 0.002 & 0.230 \\
$\beta_{6}$ & 0.007 & 0.007 & 0.322 \\
$\beta_{7}$ & -0.007 & 0.007 & 0.296 \\
$\beta_{8}$ & -0.002 & 0.004 & 0.693 \\
$\beta_{9}$ & -0.006 & 0.004 & 0.192 \\
\hline
\end{tabular}

Berdasarkan Tabel 1 dengan menggunakan taraf signifikansi $(\alpha)$ sebesar 0.1 maka variabel yang signifikan yaitu yang memiliki p-value $<\alpha$ adalah variabel Rasio Jumlah Puskesmas per 30.000 Penduduk pada masing-masing provinsi di Indonesia $\left(X_{2}\right)$.

\section{Kesimpulan}

Berdasarkan hasil analisis dan pembahasan mengenai model resgresi Poisson, variabel prediktor yang signifikan adalah Rasio jumlah puskesmas per 30.000 penduduk pada masing-masing provinsi di Indonesia $\left(X_{2}\right)$. Pada penelitian ini pengolahan untuk regresi Poisson ini mengalami overdispersi sehingga peneliti menganjurkan untuk penelitian selanjutnya agar dapat melakukan penanganan terhadap kasus overdispersi. Pengaruh signifikan dari variabel prediktor yang diperoleh terhadap model tidak relevan dengan fakta yang ada maka diduga ada faktor lain yang berpengaruh terhadap AKI sehingga untuk peneliti selanjutnya diharapkan dapat menambah faktor-faktor penyebab kemungkinan terjadinya kasus kematian ibu dan bayi di Indonesia.

\section{Daftar Pustaka}

[1] Bain, L.J and M. Engelhardt. 1991. Introduction to Probability and Mathematical Statistics. Second Edition. Duxbury Press, California.

[2] Kementerian Kesehatan Republik Indonesia. 2014. Profil Data Kesehatan Republik Indonesia 2014. Kementerian Kesehatan Republik Indonesia, Jakarta. ( Diakses pada tanggal 6 Januari 2018 pukul 16.45 WIB ) 
[3] Kementerian Kesehatan Republik Indonesia. 2014. Info Datin 2014. Kementerian Kesehatan Republik Indonesia, Jakarta. ( Diakses pada tanggal 6 Januari 2018 pukul 16.45 WIB )

[4] Walpole, R.E. 1982. Pengantar Statistika.Edisi Ketiga. PT. Gramedia Pustaka Tama, Jakarta.

[5] Yulianingsih, K.A, Komang, G.S, dan Luh, P.S. 2012. Penerapan Regresi Poisson untuk Mengetahui Faktor-Faktor yang Mempengaruhi Jumlah Siswa SMA/SMK yang Tidak Lulus UN Di Bali. E-Journal Matematika. 1: 59 - 63 